\title{
Sustainability in an era of emerging infectious diseases
}

The outbreak of the coronavirus COVID-19 earlier this year took the world by surprise.The long-term consequences of this emerging infectious disease (EID) are impossible to predict. Currently, disruption in every economic sector, unprecedented demands on health services everywhere, let alone human morbidity and mortality, are already highly visible through saturated media coverage. The Academy of Science of South Africa recently issued a measured Statement on the Implications of Novel Coronavirus (SARS-CoV-2; COVID-19) in South Africa that is worth reading. A recent 'Opinion' in the Proceedings of the National Academy of Sciences of the United States of America alerts us to the effects of a pandemic risk that threatens progress towards all the Sustainable Development Goals (SDGs). ${ }^{1}$

A number of articles in this issue of SAJS are of relevance to the topic of SDGs. One that now takes on a fresh resonance in the age of EIDs is the review by Catherine Burns of Howard Phillips's book In a Time of Plague: Memories of the 'Spanish' Flu Epidemic of 1918 in South Africa. As an historian of medicine, Phillips has contributed to the literature on this flu epidemic ${ }^{2,3}$, but here he presents personal, first-hand accounts of the impact of the epidemic in South Africa. Drawing on interviews and letters, and quoting poetry, songs and reminiscences of an unforgettable period of disease that claimed the lives of 50 million people worldwide, this book has implications for reaching SDG 3, 'Good health and wellbeing', with our own imminent threats of large-scale illnesses and limited resources with which to treat them.

Other Book Reviews also relate to SDGs. Hettie Schönfeldt analyses the late Renata Coetzee's A Feast from Nature: Food Culture of the First Humans on Planet Earth that aligns with SDG 2, 'Zero hunger'. Should food imports be affected by EIDs, greater knowledge, and more appreciation, of local crop varieties and indigenous animal breeds gains increased significance. SDG 4, 'Quality education', is the topic of Chris Brink's The Soul of a University: Why Excellence Is Not Enough, reviewed by Harry Boyte. Already challenged by student disruptions, it is certain that EIDs will create even more difficulties to the education sector. Sydney Moyo reviews an important reference work relating to SDG 6 , 'Clean water and sanitation'. Multiple Stressors in River Ecosystems: Status, Impacts and Prospects for the Future, edited by Sergi Sabater, Arturo Elosegi and Ralf Ludwig, includes the latest knowledge of the pressures facing the ecology and management of running waters, while Alan Whitfield's Fishes of Southern African Estuaries: From Species to Systems, reviewed by Peter Moyle, alerts us to the importance of SDG 14, 'Life below water'. There are also three Commentaries that highlight other SDGs. One, 'All materials great and small', is by Alexander Quandt of the School of Physics at Wits and the 2018/2019 NSTF-South32 Special Annual Theme Award winner. In charting his own career in the field of materials science, Quandt highlights the critical importance of innovation and creative science that relates to SDG 9, 'Industry, innovation and infrastructure. Nithaya Chetty, Dean of Science at the University of the Witwatersrand, also gives pause for thought to SDG 9, from the perspective of the university curriculum and his essay also has implications for SDG 4, 'Quality education'. In 'Reinventing inventiveness in science', Chetty argues that the future of the South African academy and economy depends on training an increasing number of highly qualified postgraduates who can readily be employed outside academia and be sought after for their innovative perspectives. The other, titled 'From reindeer to rhino: Reflections on 'Climate change mitigation and adaptation benefits of wilder rangelands", is by Graham Kerley and Joris Cromsigt who initiated a network of scientists and managers in South Africa and Sweden to refresh the rangeland debate in South Africa in the face of climate change. Theirs is a contribution to SDG 13, 'Climate action', as well as to SDG 15, 'Life on land'.

Research Articles in this issue also speak powerfully to the SDGs. SDG 16, 'Peace, justice and strong institutions', is the theme of Sikanyiso Masuku and Sharmla Rama's contribution, 'Government and civil society in South Africa: Collaboration and challenges in securing refugee rights'. They present a case study of the numerous bureaucratic and institutional difficulties that confront Congolese refugees in Pietermaritzburg in securing their legal rights to employment, education and health care. 'Gender pay transparency mechanisms: Future directions for South Africa', by Anita Bosch and Shimon Barit, directly addresses SDG 5, 'Gender equality'. As is well known, gender pay discrimination remains a stumbling block in achieving gender equality and by making gender wage differentials more transparent, employers may be compelled to remunerate fairly and equally.

Matthew McGill and co-authors contribute 'Observation and quantification of aerosol outflow from southern Africa using spaceborne lidar', relating to SDG 7, 'Affordable and clean energy'. They demonstrate how biomass burning in Africa provides a prolific source of aerosols that are transported from source to very distant areas. Models have long predicted the primary outflow and transport routes, but lidar on the International Space Station has detection sensitivity that supports long-held theories of aerosol transport from the African subcontinent as far downstream as Australia. 'Sciarid pests (Diptera: Sciaridae) from undercover crop production in South Africa' by Agil Katumanyane and co-authors homes in on SDG 2, 'Zero hunger'. In this multidisciplinary contribution the authors explain how and why fungus gnats (sciarids) are some of the most important pests in undercover crop production, causing direct physical damage to plant roots, transferring fungal pathogens and creating entry points for soilborne plant pathogens.

The research article by Omosalewa Odebiri and co-authors has implications for SDG 13, 'Climate action' and also for SDG 15, 'Life on land'. Titled 'Estimating soil organic carbon stocks under commercial forestry using topo-climate variables in KwaZulu-Natal, South Africa', they emphasise soil as the largest carbon reservoir but point out that the relationship between soil organic carbon in commercial forests and topo-climatic variables is still poorly understood. They argue that bridging this knowledge gap is essential for quantifying local, regional or global carbon balances.

The coronavirus outbreak has not only reminded us that humanity remains in what John Kenneth Galbraith described in 1977 as The Age of Uncertainty ${ }^{5}$, and that our socio-economic structures are fragile, but also that there is even more urgency to make progress in reaching sustainable development.

\section{References}

1. Di Marco H, Baker ML, Daszak P, De Barro P, Eskew EA, Godde CM, et al. Opinion: Sustainable development must account for pandemic risk. Proc Natl Acad Sci USA. 2020;117(8):3888-3892. https://doi.org/10.1073/pnas.2001655117

2. Phillips H, Killingray D, editors. The Spanish influenza pandemic of 1918-19: New perspectives. London: Routledge; 2003.

3. Phillips H. Black October: The impact of the Spanish influenza epidemic of 1918 on South Africa. Pretoria: Government Printer; 1990.

4. US Centers for Disease Control and Prevention. 1918 Pandemic (H1N1 virus) [webpage on the Internet]. No date [updated 2019 Mar 20; cited 2020 Mar 03]. Available from: https://www.cdc.gov/flu/pandemic-resources/1918-pandemich1n1.html

5. Galbraith JK. The age of uncertainty. Boston: Houghton Mifflin; 1977.

Note: Issue 116(1/2) included an Invited Commentary by Fortunate M. Phaka on 'Environmental science investigations of folk taxonomy and other forms of indigenous knowledge'. We have been asked to note formally that this contribution was not peer reviewed and that the images used were borrowed from an as-yet unpublished paper by Phaka.

HOW TO CITE:

Carruthers J. Sustainability in an era of emerging infectious diseases. S Afr J Sci. 2020;116(3/4), Art. \#8043, 1 page. https://doi.org/10.17159/sajs.2020/8043 